\title{
Editorial: Reflections on research - connecting with creativity and transformation
}

\section{DrJanet E. Penny}

There are few areas of our lives that are not shaped by research in some way: from the more concrete aspects of experience (such as the clothes we wear, the food we consume, the medications for health, the layout of buildings we enter) to the more complex ways in which we live our lives. Everything is shaped by empirical research - whether qualitative or quantitative. Not only is research part of the experience of living but it speaks to what it means to be human. There is an innate curiosity in people (Kidd \& Yaden, 2015). Humans are fundamentally inquirers with an interest to discover what is new and research is an expression of that inquiring tendency in systematic form (e.g., Cooper, 2008; McLeod, 2013). We are continually engaging with the world, seeking to understand, transform, control and make sense of our lived experience and ecology.

The origin of the word 'research' is linked with the Latin word for 'circle', in the sense of 'going round' or to 'explore thoroughly' (Cresswell, 2010: 390). However, at times, in my experience as a trainer in counselling and psychotherapy, research students can rather feel as if they are getting stuck going round in circles as they learn to make sense of the complexities of the research process. Fortunately, research assures me that this is not solely down to my particular teaching style but is a common experience; research students are impacted not just cognitively but emotionally and experientially by engaging with research (e.g., Cooper, Chenail \& Fleming, 2012). Research can be daunting for newcomers as my own article in this issue highlights, and it is rarely the topic in the curricula that students look forward to the most. Moreover, published research tends to only recount the research triumphs, often glossing over the problems that arise. As West and Hanley point out, 'Rarely does it seem we hear or read of research attempted that resulted in abject failure. This creates unreal expectations particularly for novice researchers' (2006: 209). All of this, and more, contributes to the unfriendly relationship people can have with systematic research (e.g., Berman et al, 2017) and it can occlude research's potentiality for discovery, creativity, innovation and transformation.

Action research methodologies have long understood research's potential for transformation and to contribute to human flourishing (Reason \& Bradbury, 2008: 4). Most research, however tangentially, usually seeks to improve lives - an aim that coheres somewhat with a Christian perspective. Moreover, the capacity for creativity and to bring about something new, whether in terms of knowledge or problem solving that research requires (Van Aken, 2016), is resonant with the idea that human beings are made in the image of the Divine Creator. Gabora is clear in her discussion of creativity that this capacity is inherently human, saying, 'Creativity is arguably our most uniquely human trait. It enables us to escape the present, reconstruct the past, and fantasize about the future, to visualize something that does not exist and change the world with it' (Gabora, 2013: 1548). Arguably, participation in the research process, far from being alien, can connect us with what is good in ourselves.

This issue of the Waverley College Journal offers a number of articles that have engaged with the research process in some way. Lucy Thomas' qualitative investigation of courage throws a light on an under-researched and important area of clinical practice. The timely piece by Sookyung Yang explores the impact of COVID-19 on Christian counsellors. Annabel Clarke's article explores some 
of the implications of Engage's research findings on the gender balance in UK churches for Christian heterosexual marriage and the Church. Charlotte Wears adds to the small but growing body of empirical research on the Waverley integrative framework (WIF) in her research on students' experiences of integrating the WIF in practice. Although not formally framed by a research methodology, the work of Sarah Armitage and her colleagues, Mary Sam, Sochenda San and Wendy Scott, bears some of the hallmarks of good participatory action research as they wrestle with teaching the Waverley integrative framework in the Cambodian context. And finally, the 'Research Pond' is offered by myself as a tool to aid learning research methodology with some reflections on research from a Christian perspective and an invitation to continue the dialogue. Good research has something to say in response to the 'So what?' question and it is hoped that these articles will be of service in their respective areas of research.

\section{References}

Berman, M. I., Chapman, N., Nash, B., Kivlighan, D. M. \& Paquin, J. D. (2017) Sharing wisdom: Challenges, benefits, and developmental path to becoming a successful therapist-researcher, Counselling Psychology Quarterly, 30 (3), pp. 234-254.

Cooper, M. (2008) Essential Research Findings in Counselling and Psychotherapy: The Facts are Friendly, London: Sage Publications.

Cooper, R., Chenail, R. J. \& Fleming, S. (2012) A grounded theory of inductive qualitative research education: Results of a meta-data-analysis, The Qualitative Report 17 (52): pp. 1-26.

Creswell (2010) Oxford Dictionary of Word Origins, $3^{\text {rd }}$ Edn, Oxford: Oxford University Press.

Gabora, L. (2013) Research on creativity, In Elias G. Carayannis (Ed.) Encyclopedia of

Creativity, Invention, Innovation, and Entrepreneurship (1548-1558), New Delhi, India: Springer.

Kidd, C. \& Yaden, B. Y. (2015) The psychology and neuroscience of curiosity, Neuron, 88 (3), pp. 449-460.

McLeod, J. (2013) An Introduction to Research in Counselling and Psychotherapy, London: Sage Publications, Ltd.

Reason, P.\& Bradbury, H. (2008) Introduction to groundings, In, P. Reason \& H. Bradbury (Eds), The SAGE Handbook of Action Research, $2^{\text {nd }}$ Edn, London: Sage Publications Ltd.

Van Aken, K. L. (2016) The critical role of creativity in research, MRS Bulletin, 41, pp. 934-935.

West, W. \& Hanley, T. (2006) Technically incompetent or generally misguided: Learning from a failed counselling research project, Counselling and Psychotherapy Research, 6 (3), pp. 209-212.

\section{Copyright}

Copyright 2021 Dr Janet E. Penny 